\title{
ANALISA VARIASI WAKTU FERMENTASI PEMBUATAN BIOETANOL DENGAN BAHAN KULIT SINGKONG DAN KULIT NANAS
}

\author{
Rachmat Subagyo ${ }^{1)}$, Wahyu Arifin ${ }^{2)}$ \\ ${ }^{1,2}$ Program Studi Teknik Mesin \\ Fakultas Teknik Universitas Lambung Mangkurat \\ Jl. Akhmad Yani Km. 36 Banjarbaru, Kalimantan Selatan \\ Telp. 0511-4772646, Fax 0511-4772646 E-mail: \\ arifinw336@gmail.com
}

\begin{abstract}
This study studied the best levels of bioethanol from a combination of cassava peel and pineapple peel mixtures with 6 gram yeast mass and 72 hours, 96 hours and 120 hours fermentation time, to determine the optimal fermentation time and find ethanol levels according to SNI. This research was carried out by hydrolysis or cassava peel and pineapple peel using aquades for 30 minute to break the molecule into two parts, then carried out the fermentation process using Saccharomyces Cerevisae (yeast) and the distillation process using a destilator to obtain ethanol for fermentation then tested with a Refractometer to determine whether there is an ethanol level formed from the distillation process. The best sample selected was then tested for ethanol content using the Gas Chromatography tool. The results of this study are known by using the Gas Chromatography tool to determine the ethanol content contained in the distilled sample, the highest ethanol content of each combination. So that the best ethanol yield from a combination of $100 \%$ cassava peel - 0\% Pineapple Peel with a duration of 120 hours fermentation producing ethanol of $89.81 \%$ is still not included in the SNI category.
\end{abstract}

Keywords : Ethanol, Fermentation, Cassava Peel, Pineapple Peel \& Hydrolysis

\section{PENDAHULUAN}

Menipisnya cadangan bahan bakar fosil dan semakin meningkatnya populasi manusia sangat berpengaruh terhadap kebutuhan energi bagi kelangsungan hidup manusia. Sejak lima tahun terakhir, Indonesia mengalami dampak penurunan produksi minyak nasional. padahal dengan menambahnya jumlah penduduk indonesia, semakin meningkat pula kebutuhan akan sarana transportasi dan aktivitas industri. Hal ini berakibat pada peningkatan kebutuhan dan konsumsi bahan bakar minyak.

Oleh karena itu sudah saatnya untuk Indonesia mencari alternatif lain, dimana sumber energi fosil yang sifatnya tidak terbarukan beralih ke sumber energi berbahan baku nabati yang sifatnya terbarukan. Sebagai negara agraris dan tropis, Indonesia telah dianugerahi kekayaan alam yang melimpah yang dapat dimanfaatkan sebagai bioenergi. Bahan bakar berbasis nabati salah satu contohnya adalah bioetanol. Bioetanol merupakan senyawa alkohol yang diperoleh lewat proses fermentasi biomassa dengan bantuan mikroorganisme. Bioetanol dapat dibuat dari sumber daya hayati yang sangat melimpah di Indonesia contohnya dari bahan-bahan bergula atau pati seperti Kuluit singkong, Kulit nanas, tebu, nira, sorgum, ubi jalar, dan lain-lain. Semuanya merupakan tanaman yang memiliki karbohidrat dan mudah ditemukan di indonesia karena keadaan tanah dan iklim yang sangat mendukung. 
Etanol adalah senyawa organik yang terdiri dari karbon, hidrogen dan oksigen, sehingga dapat dilihat sebagai derivat senyawa hidrokarbon yang mempunyai gugus hidroksil dengan rumus $\mathrm{C}_{2} \mathrm{H}_{5} \mathrm{OH}$. Etanol merupakan zat cair, tidak berwarna, berbau spesifik, mudah terbakar dan menguap, dapat bercampur dengan air dengan segala perbandingan.

Singkong (Manihot Esculenta Crantz) yang sering dikenal sebagai ketela pohon atau ubi kayu. Dalam bahasa Inggris bernama Cassava adalah pohon tahunan subtropika dan tropika dari keluarga Euphorbiaceae. Di Indonesia ubi kayu dinilai sebagai sumber karbohidrat yang paling potensial untuk diolah menjadi bioetanol. Hal ini dikarenakan ubi kayu memiliki daya tahan yang cukup tinggi terhadap penyakit dan dapat diatur waktu panennya serta dapat tumbuh di tempat yang memiliki tanah kurang subur. Namun di lingkungan masyarakat yang menjadi limbah yaitu pada kulit singkong itu sendiri.

Kulit singkong merupakan limbah dari singkong yang memiliki kandungan karbohidrat tinggi dan dapat digunakan sebagai sumber pakan ternak. Persentase Kulit singkong mengandung 67,73\% Air, 1,86\% Abu, 1,44\% Lemak Kasar, 10,59\% Serat Kasar , 6,03\% Protein Kasar. (Laboratorium Fakultas Peternakan, Universitas Diponegoro, 2008)

Selain kulit singkong, kulit nanas juga digunakan sebagai bahan utama pada penelitian ini. Nanas (Ananas Comosus L.) merupakan salah satu jenis buahbuahan yang banyak dihasilkan di Indonesia. Bagian utama yang bernilai ekonomis dari nanas adalah buahnya. Buah nanas selain dikonsumsi segar juga diolah menjadi berbagai macam minuman dan makanan, seperti selai nanas, buah dalam sirup dan sebagainya. Selain buahnya, bagian lain dari nanas dapat dimanfaatkan seperti kulit buah nanas itu sendiri. Tetapi bagi masyarakat kulit nanas tersebut disebut limbah yang tidak begitu berguna dan hanya dapat dimanfaatkan sebagai campuran pakan ternak yang disebut silase. Kandungan kulit nanas $86,70 \%$ air, $0,69 \%$ protein, $0,02 \%$ lemak, $0,48 \%$ abu, $1,66 \%$ serat basah, 10,54\% karbohidrat. (Wijana dkk,1991)

Dalam pembuatan bioetanol, bahan yang akan diolah menjadi bioethanol harus melalui beberapa proses yaitu proses hidrolisis, fermentasi dan destilasi. Hidrolisis adalah suatu proses antara reaktan dengan air agar suatu senyawa pecah terurai. Reaksi Hidrolisis:

$\left(\mathrm{C}_{6} \mathrm{H}_{10} \mathrm{O}_{5}\right) n+n \mathrm{H}_{2} \mathrm{O} \longrightarrow n \mathrm{C}_{6} \mathrm{H}_{12} \mathrm{O}_{6}$

Pati Air Glukosa

Reaksi antara pati dan air cukup berlangsung sangat lambat sehingga diperlukan bantuan katalisatoruntuk memperbesar kereaktifan air. Katalisator bisa berupa asam maupun enzim. Katalisator asam yang sering digunakan adalah asam klorida, asam nitrat dan asam sulfat. Dalam industri umumnya digunakan enzim sebagai katalisator.

Salah satu proses hidrolisis yaitu hidrolisis dengan katalis asam dimana katalisatornya menggunakan asam. Fungsi dari Asam sebagai katalisator dengan mengaktifkan air dari kadar asam yang encer. biasanya kecepatan reaksi sebanding dengan ion $\mathrm{H}^{+}$tetapi pada konsentrasi yang tinggi hubungannya tidak terlihat lagi. Di dalam industri asam yang dipakai adalah $\mathrm{H}_{2} \mathrm{SO}_{4}$ dan $\mathrm{HCl}$. $\mathrm{HCl}$ lebih menguntungkan karena lebih reaktif dibandingkan $\mathrm{H}_{2} \mathrm{SO}_{4}$. (Groggins, 1992)

Fermentasi adalah suatu kegiatan penguraian bahan - bahan karbohidrat yang tidak menimbulkan bau busuk dan menghasilkan gas karbondioksida. jika fermentasi busuk berarti fermentasi yang mengalami kontaminasi pada saat proses penutupan tidak rapat atau tidak kedap udara. Fermentasi gula oleh ragi 
contohnya Saccharomyces cerevisiae dapat menghasilkan etil alkohol (etanol) dan $\mathrm{CO}_{2}$ melalui reaksi sebagai berikut:

$$
\mathrm{C}_{6} \mathrm{H}_{12} \mathrm{O}_{6} \text { Saccharomyces cerevisiae } 2 \mathrm{C}_{2} \mathrm{H}_{5} \mathrm{OH}+2 \mathrm{CO}_{2}
$$

$$
\text { Glukosa } \longrightarrow \quad \text { etanol }
$$

Reaksi ini merupakan dasar dari pembuatan tape, brem, tuak, anggur minuman, bir, roti dan lain - lain (Winarno, 1984).

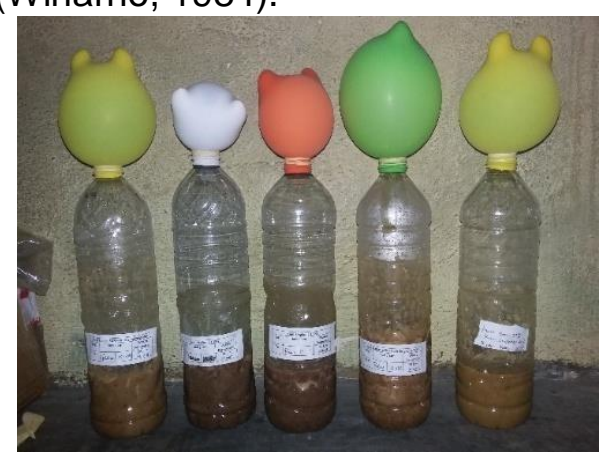

Gambar 1. Proses Fermentasi

Dalam pembuatan bioethanol tidak lepas dari proses destilasi. Destilasi adalah cara pemisahan zat cair dari campurannya berdasarkan perbedaan titik didih atau berdasarkan kemapuan zat untuk menguap. Dimana zat cair dipanaskan hingga titik didihnya, serta mengalirkan uap ke dalam alat pendingin (kondensor) dan mengumpulkan hasil pengembunan sebagai zat cair.

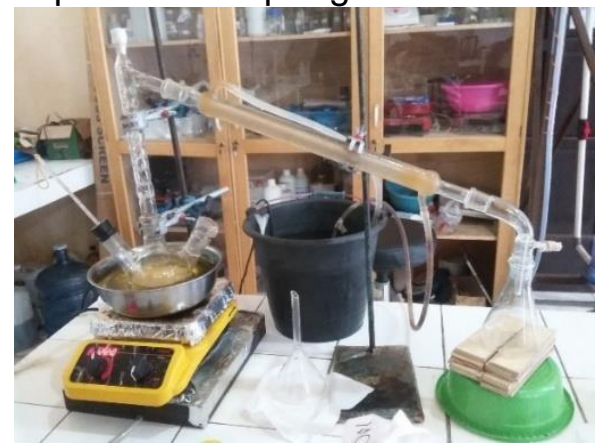

Gambar 2. Proses destilasi

Tujuan destilasi adalah pemurnian zat cair pada titik didihnya, dan memisahkan cairan tersebut dari zat padat yang terlarut atau dari zat cair lainnya yang mempunyai perbedaan titik didih cairan murni. Pada destilasi biasa tekanan uap di atas cairan adalah tekanan atmosfer (titik didih normal). Untuk senyawa murni, suhu yang tercatat pada termometer yang ditempatkan pada tempat terjadinya proses destilasi adalah sama dengan titik didih destilat (Sahidin, 2008).

Pemanfaatan bioetanol diarahkan untuk memberikan kontribusi yang signifikan terhadap bauran energi nasional terutama sebagai bahan bakar pencampur ataupun pensubstitusi bensin. Pemerintah melalui Dewan Standarisasi Nasional (DSI) telah menetapkan Standar Nasional Indonesia (SNI) untuk bioetanol dengan tujuan melindungi konsumen (dari segi mutu), produsen dan mendukung perkembangan industri bioetanol di Indonesia. Kadar etanol menurut Badan Standarisasi Nasional Indonesia adalah 94,0\%. Pada penelitian ini kadar etanol yang didapat kemudian dihitung nilai randemennya. 
Randemen adalah perbandingan jumlah (kuantitas) etanol yang dihasilkan dari proses destilasi. Adapun rumus untuk menghitung randemen adalah sebagai berikut:

$$
\text { randemen }(\%)=\frac{j \text { jumlah etanol yang dihasilkan (gram) }}{\text { jumlah bahan sebelum di olah }(\text { gram })} \times 100 \%
$$

massa $($ gram $)=$ volume bahan $(\mathrm{ml}) x$ density bahan

Hasil data perhitungan randemen dapat dilihat pada Tabel.

\section{METODE PENELITIAN}

\section{2a. Alat Dan Bahan Penelitian}

Alat yang digunakan dalam penelitian ini yaitu: Botol, balon, blender, oven, kompor, destilator, gelas ukur, saringan, timbangan digital, termo gun, botol sempel, pen refractometer. Sedangkan untuk bahan yang digunakan yaitu Kulit singkong (Manihot Esculenta Crantz), Kulit nanas (Ananas Comosus L.) dan ragi roti (Saccharomeyces Cereviseae) fermipan.

\section{2b. Pengolahan Bahan}

Kulit singkong dan kulit nanas yang sudah dikumpulkan dicuci hingga bersih. Kulit Singkong kemudian dikeringkan menggunakan oven dengan temperatur pengeringannya $100^{\circ} \mathrm{C}$ selama 30 menit, sedangkan untuk kulit nanas hanya ditiriskan. Hasil pengeringan kemudian dihaluskan dengan blender hingga diperoleh tepung dari kulit singkong dan bubur kulit nanas.

\section{2c. Proses Hidrolisis}

Pada proses ini masing-masing bahan kulit singkong dan kulit nanas ditimbang sesuai dengan kombinasi campuran perbandingan berat bahan.

Kombinasi 1 : 100\% kulit singkong dan 0\% Kulit nanas

Kombinasi 2 : $75 \%$ kulit singkong dan 25\% kulit nanas

Kombinasi 3 : 50\% kulit singkong dan 50\% kulit nanas

Kombinasi 4 : 25\% kulit singkong dan $75 \%$ kulit nanas

Kombinasi 5 : :0\% kulit singkong dan 100\% Kulit nanas

Kemudiaan tepung kulit singkong dan kulit nanas dicampur dengan air aquades $800 \mathrm{ml}$. Selanjutnya campuran direbus selama 30 menit dengan suhu $100^{\circ} \mathrm{C}$ sambil diaduk-aduk.

\section{2d. Proses Fermentasi}

Siapkan botol yang akan digunakan sebagai tempat fermentasi. Kemudian hasil hidrolisis didinginkan dan disaring hingga tidak ada ampas dalam larutan hidrolisis. Tahap selanjutnya campurkan ragi sebanyak 6 gram dan Tutup mulut botol menggunakan balon.Lakukan prosedur yang sama dengan variasi waktu fermentasi selama 72 jam, 96 jam dan 120 Jam.

\section{2e. Proses Destilasi}

Siapkan alat dan bahan. Menyalakan pemanas alat destilasi. Tunggu beberapa saatsampai suhu yang diinginkan telah dicapai. Dalam proses destilasi ini, suhu yang ditetapkan yaitu $85^{\circ} \mathrm{C}$. Suhu dipertahankan sesuai lama proses destilasi. Lama proses destilasi untuk satu sampel sekitar 2 jam. 
Setelah sampel didapatkan, kemudian sampel tersebut ditampung di dalam gelas ukur untuk diuji kadar etanolnya.

\section{2f. Pengujian Sampel Etanol}

Bioetanol hasil proses destilasi diuji dengan alat Pen Refractometer di Laboratorium Operasi Teknik Kimia Fakultas Teknik ULM untuk mengetahui ada atau tidaknya etanol yang terkandung dalam sampel hasil destilasi, yang selanjutnya akan dilakukan pengujian di Laboratorium Energi LPPM Institut Teknologi Sepuluh Nopember dengan menggunakan alat Gas Chromatography untuk mengetahui kadar bioetanol terbaik dari 3 variasi waktu fermentasi tersebut menurut standar SNI (Standar Nasional Indonesia).

\section{2g. Diagram Alir Penelitian}

Diagram alir penelitian dapat dilihat pada gambar 3 .

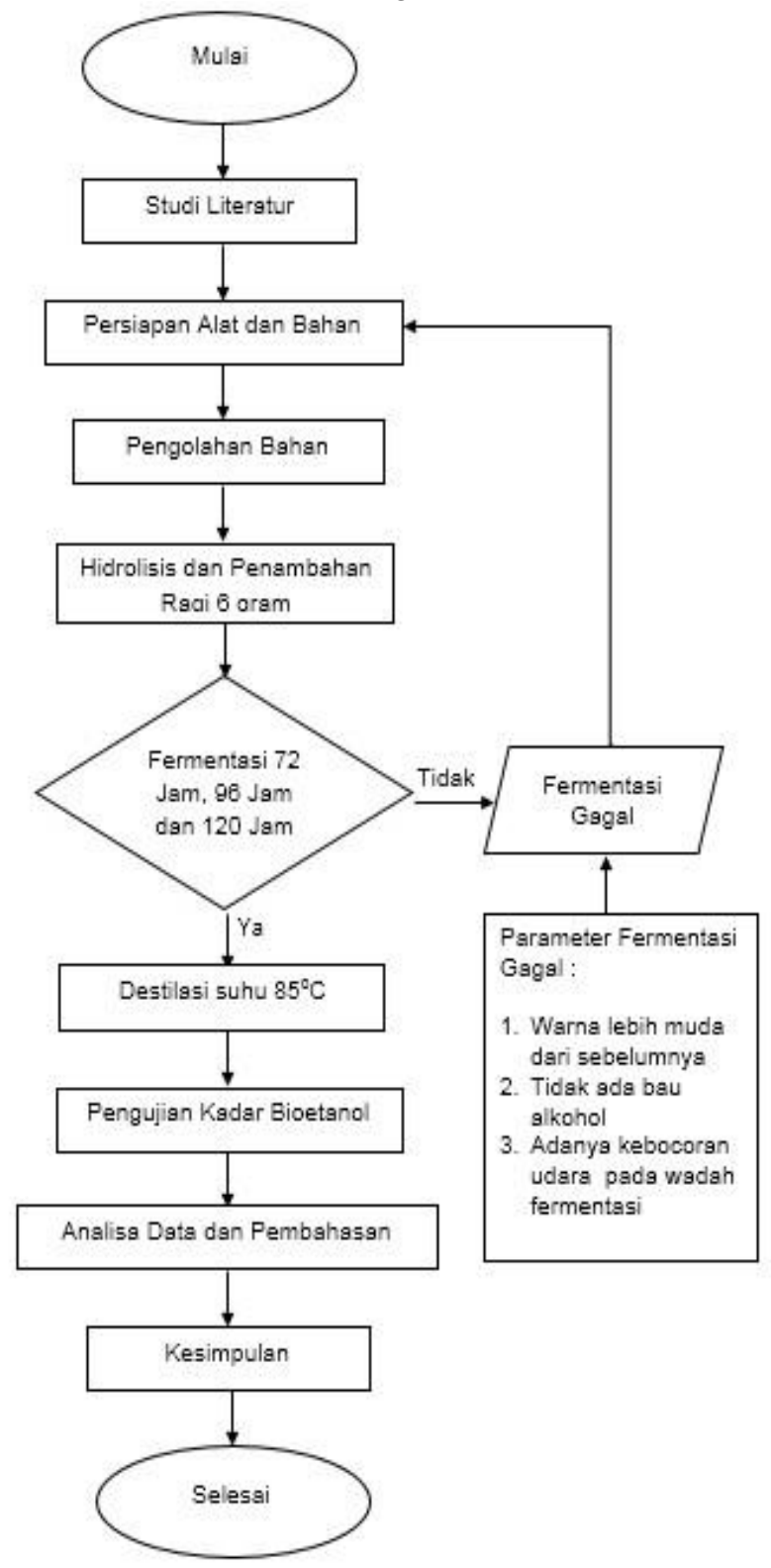

Gambar 3. Diagram penelitian 


\section{HASIL DAN PEMBAHASAN}

Dalam analisa variasi waktu fermentasi terhadap kadar etanol data yang diambil merupakan kadar etanol, volume etanol dan hasil randemen di Workshop Teknik Kimia Universitas Lambung Mangkurat dan Laboratorium Energi LPPM Institut Teknologi Sepuluh Nopember pada bulan Mei 2018 sampai dengan Juli 2018.

Tabel 1. Hasil data pengujian dengan pen refractometer, gas chromatography

\begin{tabular}{|c|c|c|c|c|c|c|c|c|c|c|}
\hline \multirow[b]{2}{*}{ No } & \multirow{2}{*}{$\begin{array}{l}\text { Jumlah } \\
\text { limbah } \\
\text { kulit } \\
\text { Singkong } \\
\text { dan Kulit } \\
\text { Nanas } \\
\text { (gram) }\end{array}$} & \multirow{2}{*}{$\begin{array}{l}\text { Massa } \\
\text { Kulit } \\
\text { Singkong } \\
\text { (gram) }\end{array}$} & \multirow{2}{*}{$\begin{array}{c}\text { Massa } \\
\text { kulit } \\
\text { Nanas } \\
\text { (gram) }\end{array}$} & \multirow[b]{2}{*}{$\begin{array}{l}\text { Air } \\
(\mathrm{ml})\end{array}$} & \multicolumn{2}{|c|}{$\begin{array}{c}\text { Jumlah } \\
\text { Perbandingan }\end{array}$} & \multicolumn{2}{|c|}{$\begin{array}{c}\text { Presentase Etanol yang terbentuk } \\
(\%)\end{array}$} & \multirow[b]{2}{*}{$\begin{array}{l}\text { Volume } \\
(\mathrm{ml})\end{array}$} & \multirow[b]{2}{*}{$\begin{array}{l}\text { Randemen } \\
(\%)\end{array}$} \\
\hline & & & & & $\begin{array}{c}\text { Massa } \\
\text { Ragi } \\
\text { (gram) }\end{array}$ & $\begin{array}{c}\text { Waktu } \\
\text { Fermentasi } \\
(\text { Jam) }\end{array}$ & $\begin{array}{c}\text { Pen } \\
\text { Refrectometer }\end{array}$ & $\begin{array}{c}\text { Gas } \\
\text { Chromatography }\end{array}$ & & \\
\hline \multirow{5}{*}{1} & \multirow{5}{*}{200} & 200 & 0 & \multirow{5}{*}{800} & \multirow{5}{*}{6} & \multirow{5}{*}{72} & 22 & - & 6 & 0,47 \\
\hline & & 150 & 50 & & & & 20,5 & - & 11 & 0,86 \\
\hline & & 100 & 100 & & & & 19 & - & 11 & 0,86 \\
\hline & & 50 & 150 & & & & 16 & - & 9 & 0,71 \\
\hline & & 0 & 200 & & & & 14 & - & 11 & 0,86 \\
\hline \multirow{5}{*}{2} & \multirow{5}{*}{200} & 200 & 0 & \multirow{5}{*}{800} & \multirow{5}{*}{6} & \multirow{5}{*}{96} & 31 & - & 6 & 0,47 \\
\hline & & 150 & 50 & & & & 29 & 83,65 & 7 & 0,55 \\
\hline & & 100 & 100 & & & & 25 & 82,82 & 9 & 0,71 \\
\hline & & 50 & 150 & & & & 20 & 26,44 & 8 & 0,63 \\
\hline & & 0 & 200 & & & & 15,5 & - & 9 & 0,71 \\
\hline \multirow{5}{*}{3} & \multirow{5}{*}{200} & 200 & 0 & \multirow{5}{*}{800} & \multirow{5}{*}{6} & \multirow{5}{*}{120} & 35 & 89,81 & 7 & 0,55 \\
\hline & & 150 & 50 & & & & 24,5 & - & 13 & 1,02 \\
\hline & & 100 & 100 & & & & 23 & - & 10 & 0,79 \\
\hline & & 50 & 150 & & & & 19 & - & 11 & 0,86 \\
\hline & & 0 & 200 & & & & 18,5 & 24,83 & 8 & 0,63 \\
\hline
\end{tabular}

\section{3a. Perbandingan Hasil Uji}

Nilai perbandingan kadar etanol pada kombinasi kulit singkong dan kulit nanas menggunakan pen refractometer dan gas chromatography dapat dilihat pada diagram perbandingan hasil uji etanol antara gas chromatography dengan pen refractometer berikut.

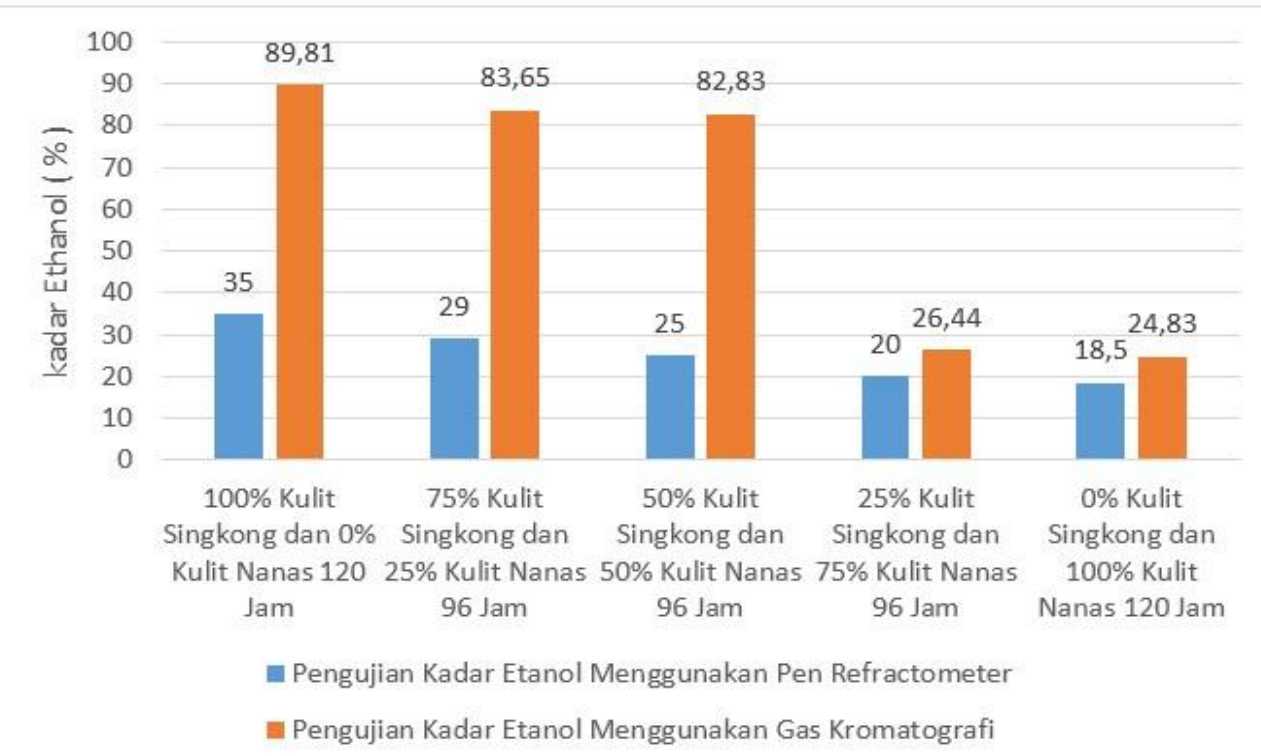

Gambar 4. Diagram Perbandingan Uji Etanol Dengan Gas Chromatograpy dengan Pen Refractometer 
Dari grafik perbandingan hasil uji kadar etanol diatas dapat dilihat bahwa data hasil pengujian kadar etanol menggunakan alat gas chromatography lebih tinggi, dibandingkan dengan data hasil pengujian kadar etanol dengan alat pen refractometer.

Hal ini disebabkan karena alat gas chromatography mempunyai tingkat ketajaman pemisah senyawa yang sangat tinggi (Widhiani, 2013). Sehingga pengujian kadar etanol dengan alat gas chromatography lebih diunggulkan karena data yang diperoleh lebih baik dibandingkan dengan data pengujian dengan pen refractometer.

\section{3b. Pengaruh Variasi Waktu Fermentasi Terhadap Kadar Etanol}

Pengaruh variasi waktu fermentasi terhadap kadar etanol dapat ditunjukan pada Gambar 5 dan Gambar 6

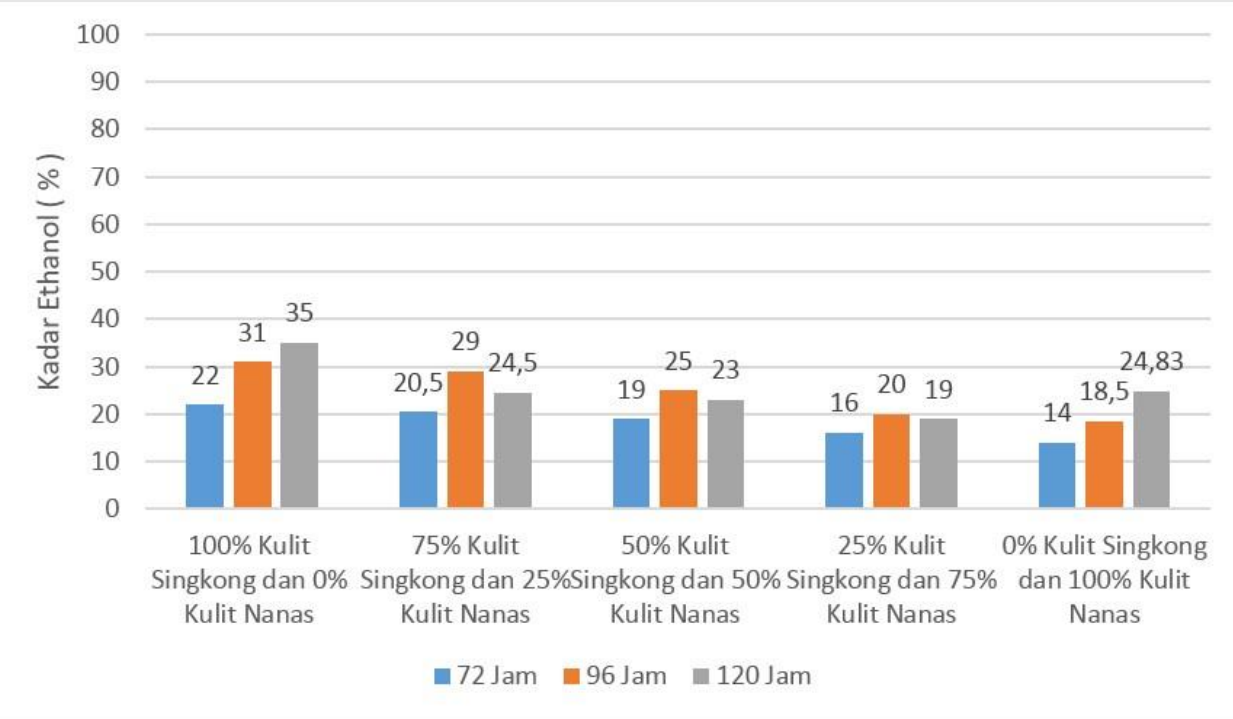

Gambar 5. Diagram Hubungan Pengaruh Variasi Waktu Fermentasi Terhadap Kadar Etanol menggunakan alat Pen Refractometer

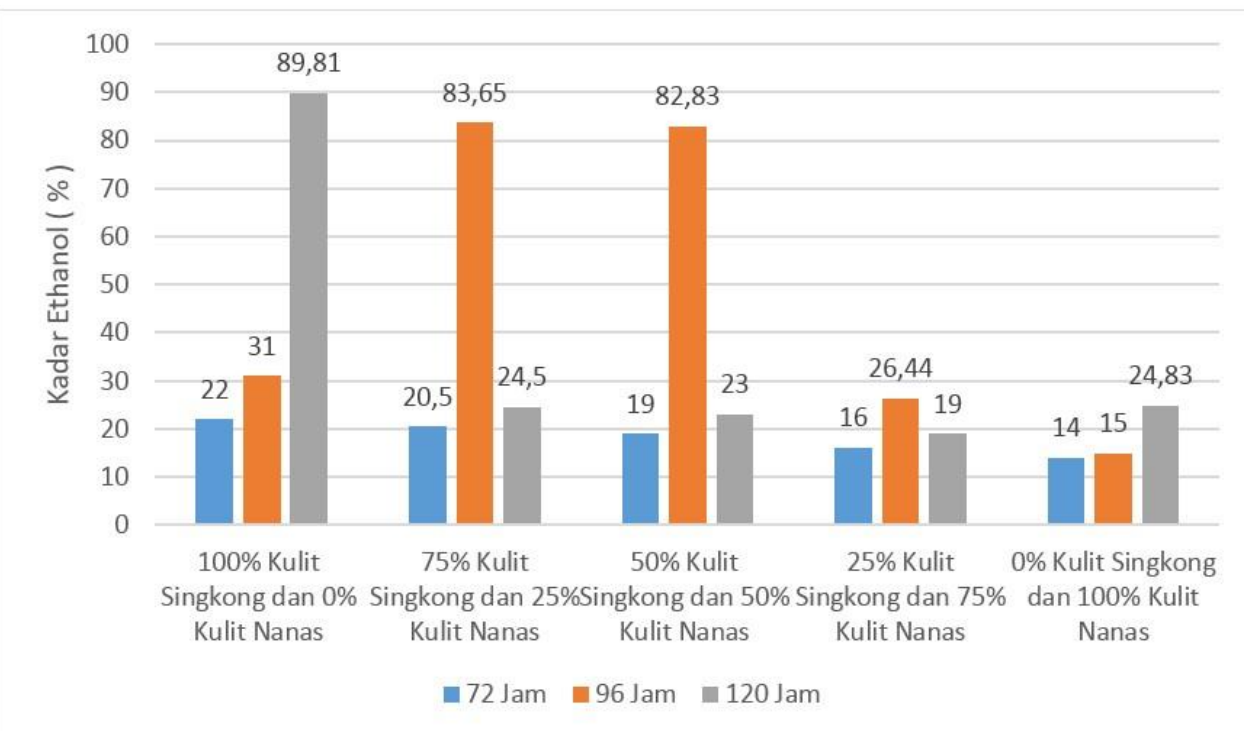

Gambar 6. Diagram Hubungan Pengaruh Variasi Waktu Fermentasi Terhadap Kadar Etanol menggunakan alat Pen Refractometer dan Gas Kromatografi 
Berdasarkan diagram pengaruh variasi waktu fermentasi terhadap kadar etanol dapat dilihat bahwa pada dua diagram tersebut alat Gas Kromatografi lebih diunggulkan karena hasil etanol lebih tinggi seperti campuran $100 \%$ kulit singkong dan $0 \%$ kulit nanas pada waktu fermentasi 120 jam menghasilkan $89,81 \%$ etanol, pada campuran $75 \%$ kulit singkong dan $25 \%$ kulit nanas hasil etanol tertinggi terdapat pada waktu fermentasi 96 jam sebesar 83,65\% etanol, pada campuran $50 \%$ kulit singkong dan $50 \%$ kulit nanas hasil tertinggi terdapat pada waktu fermentasi 96 jam sebesar $82,83 \%$ etanol, pada campuran $25 \%$ kulit singkong dan $75 \%$ kulit nanas hasil tertinggi terdapat pada waktu fermentasi 96 jam sebesar $26,44 \%$ etanol, dan pada campuran $0 \%$ kulit singkong dan $100 \%$ kulit nanas hasil tertinggi terdapat pada waktu fermentasi 120 jam sebesar $24,83 \%$ etanol. jadi dari dua diagram pengaruh waktu fermentasi terhadap kadar etanol dengan pen refractometer maupun gas kromatografi, jika terlalu cepat waktu fermentasi etanol yang dihasilkan akan sedikit disebabkan mikroorganisme yang mengurai glukosa belum berkembang secara optimal sedangkan jika terlalu lama proses fermentasi yang dilakukan etanol yang dihasilkan akan mulai menurun disebabkan aktifitas mikroorganisme sudah mulai berkurang karena mulai mendekati fase kematian. maka jika terlalu cepat proses fermentasi etanol yang dihasilkan sedikit begitu juga bila terlalu lama kadar etanol akan berkurang karena semakin lama waktu fermentasi maka kosentrasi sel mikroorganisme akan semakin menurun dan menuju pada fase decline karena kosentrasi bioetanol yang dihasilkan semakain tinggi dan kosentrasi nutrient sebagai makanan mikroorganisme semakin menurun, sehingga etanol yang dihasilkan akan berubah menjadi asam asetat (Setyawati, 2010).

\section{3c. Pertumbuhan Jamur Pada Proses Fermentasi}

Proses fermentasi tergantung pada pertumbuhan jamur. Jamur inilah yang berperan aktif dalam proses fermentasi dengan menguraikan glukosa menjadi alkohol. (Rosalia S, 2018). penulis melihat perkembangan jamur dengan menggunakan digital microscope perbesaran 1000x.

Pertumbuhan jamur pada fermentasi 100\% kulit singkong dan $0 \%$ kulit nanas.

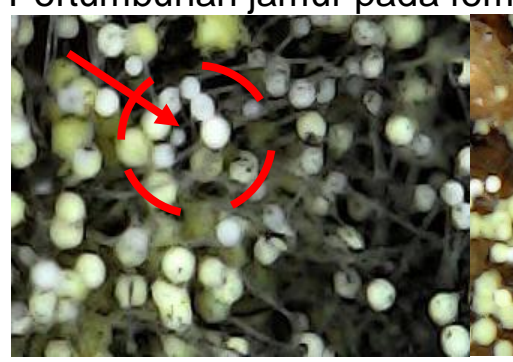

(a)

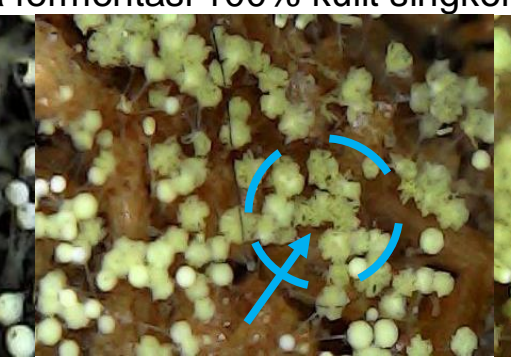

(b)

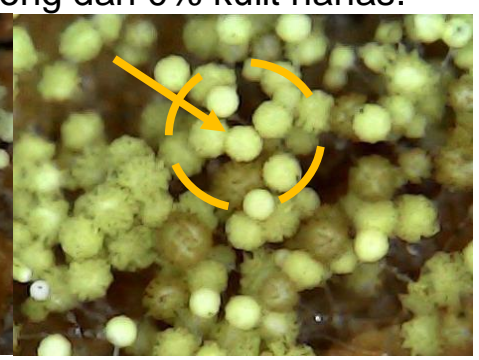

(c)

Gambar 7. Pertumbuhan Jamur pada (a). Fermentasi 72 Jam (b). Fermentasi 96 Jam (c). Fermentasi $120 \mathrm{Jam}$

Gambar (a) ditandai dengan lingkaran (warna merah) menunjukkan pertumbuhan jamur pada fermentasi 72 jam terlihat sedikit karena masih pada tahap perkembangan, Gambar (b) ditandai dengan lingkaran (warna kuning) menunjukkan pertumbuhan jamur pada fermentasi 96 jam terlihat begitu cukup banyak karena pada fermentasi selama 96 jam jamur mulai berkembang dan berubah warna menjadi hijau. Pada gambar (c) ditandai dengan lingkaran (warna biru) menunjukkan pertumbuhan jamur pada fermentasi 120 jam terus bertambah 
banyak dan tidak terjadi perubahan warna karena pada fermentasi 120 jam jamur berkembang secara optimal. Sehingga kadar etanol yang dihasilkan terus meningkat.

Pertumbuhan jamur pada fermentasi $75 \%$ kulit singkong dan $25 \%$ kulit nanas.

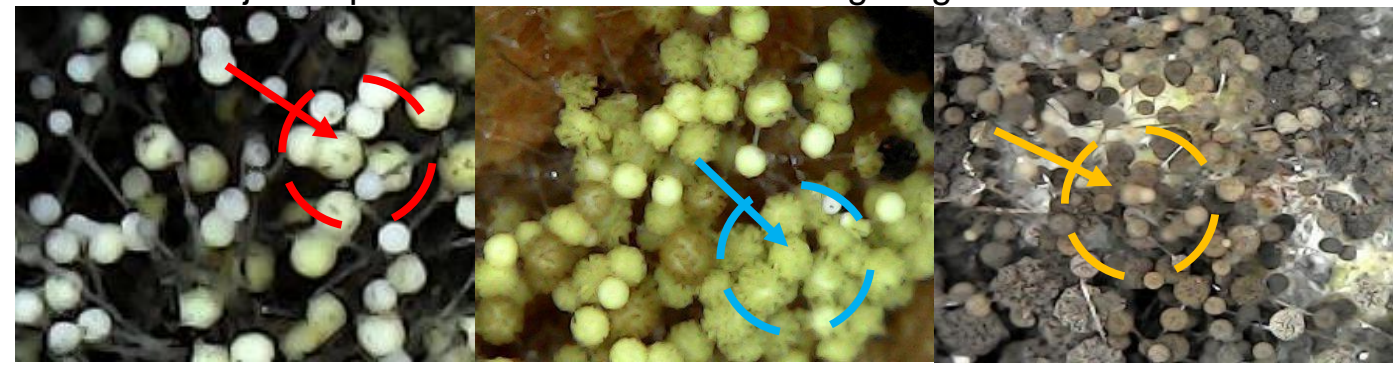

(a) (b)

Gambar 8. Pertumbuhan Jamur pada (a). Fermentasi 72 Jam (b). Fermentasi 96 Jam (c). Fermentasi $120 \mathrm{Jam}$

Gambar (a) ditandai dengan lingkaran (warna merah) menunjukkan pertumbuhan jamur pada fermentasi 72 jam pada tahap perkembangan, Gambar (b) ditandai dengan lingkaran (warna kuning) menunjukkan pertumbuhan jamur pada fermentasi 96 jam terlihat sangat begitu banyak karena pada fermentasi selama 96 jam jamur mulai berkembang seaca optimal dan warna berubah menjadi hijau dan Pada gambar (c) ditandai dengan lingkaran (warna biru) menunjukkan pertumbuhan jamur pada fermentasi 120 jam mulai berkurang dan warna mulai berubah hitam karena mulai menurunnya aktifitas jamur. Karena semakin lama proses fermentasi jamur akan mendekati fase kematian sehingga jumlah jamur akan berkurang. Maka kadar etanol yang dihasilkan pada proses fermentasi 120 jam mulai berkurang.

Pertumbuhan jamur pada fermentasi 50\% kulit singkong dan 50\% kulit nanas.

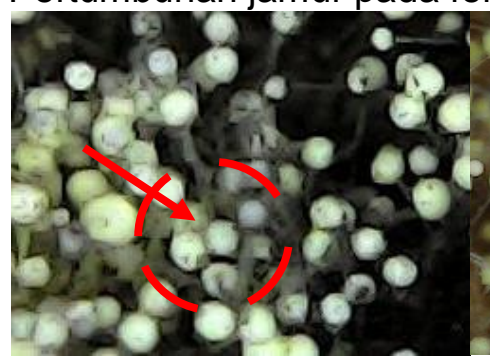

(a)

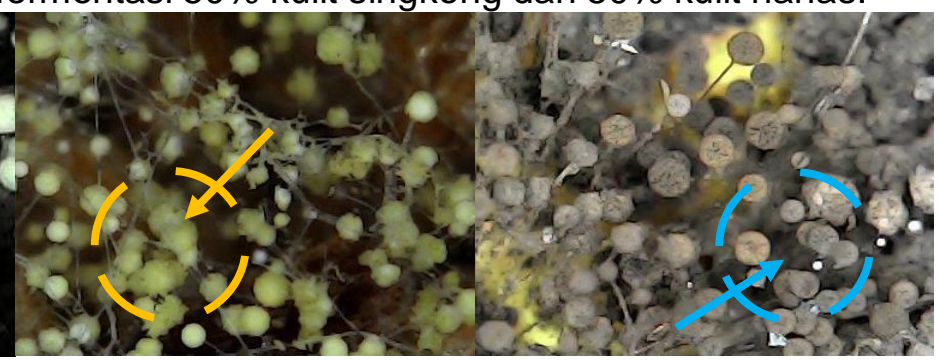

(b) (c)

Gambar 9. Pertumbuhan Jamur pada (a). Fermentasi 72 Jam (b). Fermentasi 96 Jam (c). Fermentasi $120 \mathrm{Jam}$

Gambar (a) ditandai dengan lingkaran (warna merah) menunjukkan pertumbuhan jamur pada fermentasi 72 jam pada tahap perkembangan, Gambar (b) ditandai dengan lingkaran (warna kuning) menunjukkan pertumbuhan jamur pada fermentasi 96 jam terlihat sangat begitu banyak karena pada fermentasi selama 96 jam jamur mulai berkembang seaca optimal dan warna berubah menjadi hijau dan Pada gambar (c) ditandai dengan lingkaran (warna biru) menunjukkan pertumbuhan jamur pada fermentasi 120 jam mulai berkurang dan warna mulai berubah hitam karena mulai menurunnya aktifitas jamur. Karena semakin lama proses fermentasi jamur akan mendekati fase kematian sehingga 
jumlah jamur akan berkurang. Maka kadar etanol yang dihasilkan pada proses fermentasi 120 jam mulai berkurang.

Pertumbuhan jamur pada fermentasi $25 \%$ kulit singkong dan $75 \%$ kulit nanas.

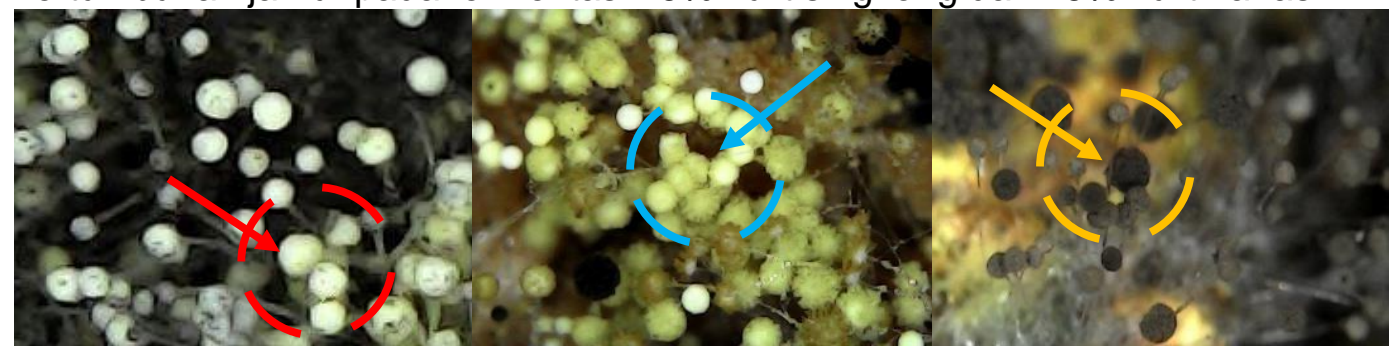

(a)

(b)

(c)

Gambar 10. Pertumbuhan Jamur pada (a). Fermentasi 72 Jam (b). Fermentasi 96 Jam

(c). Fermentasi $120 \mathrm{Jam}$

Gambar (a) ditandai dengan lingkaran (warna merah) menunjukkan pertumbuhan jamur pada fermentasi 72 jam pada tahap perkembangan, Gambar (b) ditandai dengan lingkaran (warna kuning) menunjukkan pertumbuhan jamur pada fermentasi 96 jam terlihat sangat begitu banyak karena pada fermentasi selama 96 jam jamur mulai berkembang seaca optimal dan warna berubah menjadi hijau dan Pada gambar (c) ditandai dengan lingkaran (warna biru) menunjukkan pertumbuhan jamur pada fermentasi 120 jam mulai berkurang dan warna mulai berubah hitam karena mulai menurunnya aktifitas jamur. Karena semakin lama proses fermentasi jamur akan mendekati fase kematian sehingga jumlah jamur akan berkurang. Maka kadar etanol yang dihasilkan pada proses fermentasi 120 jam mulai berkurang.

Pertumbuhan jamur pada fermentasi 0\% kulit singkong dan 100\% kulit nanas.

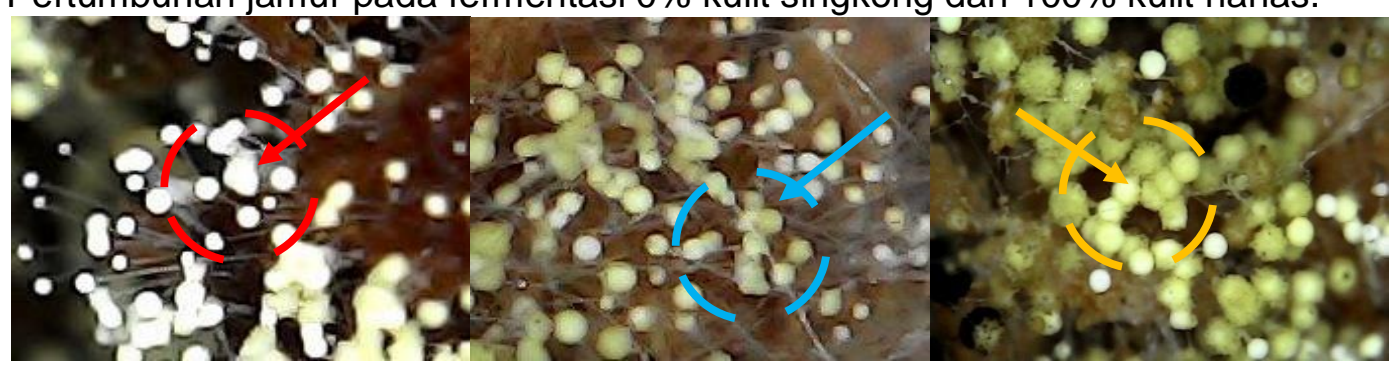

(a)

(b)

(c)

Gambar 11. Pertumbuhan Jamur pada (a). Fermentasi 72 Jam (b). Fermentasi 96 Jam

(c). Fermentasi $120 \mathrm{Jam}$

Gambar (a) ditandai dengan lingkaran (warna merah) menunjukkan pertumbuhan jamur pada fermentasi 72 jam terlihat sedikit karena masih pada tahap perkembangan, Gambar (b) ditandai dengan lingkaran (warna kuning) menunjukkan pertumbuhan jamur pada fermentasi 96 jam terlihat begitu cukup banyak karena pada fermentasi selama 96 jam jamur mulai berkembang dan berubah warna menjadi hijau. Pada gambar (c) ditandai dengan lingkaran (warna biru) menunjukkan pertumbuhan jamur pada fermentasi 120 jam terus bertambah banyak dan tidak terjadi perubahan warna karena pada fermentasi 120 jam jamur berkembang secara optimal. Sehingga kadar etanol yang dihasilkan terus meningkat. 
3d. Kualitas Kadar Etanol Menurut SNI

Tabel 2. Hasil Presentase Etanol Dibandingkan SNI

\begin{tabular}{|c|c|c|c|c|c|c|c|}
\hline \multirow[b]{2}{*}{ No } & \multicolumn{2}{|c|}{ Campuran } & \multirow[b]{2}{*}{$\begin{array}{c}\text { Massa } \\
\text { Ragi } \\
\text { (gram) }\end{array}$} & \multirow[b]{2}{*}{$\begin{array}{c}\text { Waktu } \\
\text { Fermentasi } \\
\text { (Jam) }\end{array}$} & \multirow[b]{2}{*}{$\begin{array}{l}\text { Persentase } \\
\text { Etanol (\%) }\end{array}$} & \multirow[b]{2}{*}{$\begin{array}{c}\text { Standar } \\
\text { Nasional } \\
\text { Indonesia } \\
(\%)\end{array}$} & \multirow[b]{2}{*}{$\begin{array}{l}\text { Memenuhi/ } \\
\text { Tidak } \\
\text { Memenuhi } \\
\text { Standar } \\
\text { SNI }\end{array}$} \\
\hline & $\begin{array}{c}\text { Massa } \\
\text { Kulit } \\
\text { Singkong } \\
\text { (gram) }\end{array}$ & $\begin{array}{c}\text { Massa } \\
\text { Kulit } \\
\text { Nanas } \\
\text { (gram) }\end{array}$ & & & & & \\
\hline 1 & 200 & 0 & 6 & 120 & 89,81 & \multirow{5}{*}{94,00} & $\begin{array}{l}\text { Tidak } \\
\text { Memenuhi }\end{array}$ \\
\hline 2 & 150 & 50 & 6 & 96 & 83,65 & & $\begin{array}{c}\text { Tidak } \\
\text { Memenuhi }\end{array}$ \\
\hline 3 & 100 & 100 & 6 & 96 & 82,83 & & $\begin{array}{l}\text { Tidak } \\
\text { Memenuhi }\end{array}$ \\
\hline 4 & 50 & 150 & 6 & 96 & 26,44 & & $\begin{array}{l}\text { Tidak } \\
\text { Memenuhi }\end{array}$ \\
\hline 5 & 0 & 200 & 6 & 120 & 24,83 & & $\begin{array}{c}\text { Tidak } \\
\text { Memenuhi }\end{array}$ \\
\hline
\end{tabular}

Dari tabel hasil uji kadar bioetanol menurut standar nasional Indonesia diatas. Standar Nasional Indonesia Bioetanol untuk bioetanol ialah 94,00\%. dapat dilihat bahwa dari hasil penelitian ini kadar etanol tertinggi didapat dari kombinasi 100\% Kulit Singkong dan 0\% kulit Nanas dengan variasi waktu Fermentasi 120 jam yang telah dilakukan pengujian dengan menggunakan alat Gas Chromatograpy untuk mengetahui kemurnian kadar etanol sebenarnya, Kadar etanol yang dihasilkan sebesar $89,81 \%$.

Sehingga dapat disimpulkan bahwa kadar etanol dari kombinasi 100\% Kulit Singkong dan 0\% kulit Nanas dengan variasi waktu Fermentasi 120 jam tidak masuk dalam kategori standar nasional Indonesia (SNI) untuk bioetanol.

\section{KESIMPULAN}

Kesimpulan dari penelitian tugas akhir ini adalah sebagai berikut:

1. Didapatkan hasil kadar etanol tertinggi dari setiap kombinasi campuran yaitu untuk kombinasi $100 \%$ kulit singkong - 0\% kulit nanas sebesar $89,81 \%$, kombinasi $75 \%$ kulit singkong - $25 \%$ kulit nanas sebesar $83,65 \%$, kombinasi $50 \%$ kulit singkong - 50\% kulit nanas sebesar $82,83 \%$, kombinasi $25 \%$ kulit singkong - 75\% kulit nanas sebesar 26,44\%, kombinasi 0\% kulit singkong - 100\% kulit nanas sebesar 24,83\% kadar etanol yang dihasilkan.

2. Waktu yang optimum untuk fermentasi dari kombinasi $100 \%$ kulit singkong $0 \%$ kulit nanas dan kombinasi $0 \%$ kulit singkong - 100\% kulit nanas mendapatkan waktu yang optimum untuk fermentasi selama 120 jam. Sedangkan pada kombinasi $75 \%$ kulit singkong - 25\% kulit nanas, kombinasi

$50 \%$ kulit singkong - 50\% kulit nanas, dan kombinasi 25\% kulit singkong $75 \%$ kulit nanas mendapatkan waktu yang optimum untuk fermentasi selama 96 jam.

3. Dari penelitian ini kadar etanol tertinggi didapat dari $100 \%$ kulit singkong dan $0 \%$ kulit nanas dengan variasi waktu fermentasi 120 Jam, menghasilkan kadar etanol 89,81\%. Sehingga dapat disimpulkan bahwa kadar etanol yang dihasilkan tidak masuk dalam kategori SNI. 


\section{DAFTAR PUSTAKA}

Bandar Standardisasi Nasional. 2008. SNI 7290:2008. Bioethanol Terdenaturasi untuk gasohol. Jakarta.

Groggins. 1992. Unit Processes in Organic Synthesis. Mc Graw Hill. Singapore.

Sahidin, 2008, Penuntun Praktikum Kimia Organik I, Unhalu, Kendari.

Selmi Rosalia. 2018. Pengaruh Lama Fermentasi Terhadap Kadar Alkohol, Warna, rasa Dan AromaTuak Ubi Jalar Ungu. Universitas Sanata Dharma. Yogyakarta

Setyawati. H dan N.A Rahman., 2010, "Bioetanol Dari Kulit Nanas Dengan Variasi Massa Saccharomyces Cereviceae Dan Waktu Fermentasi, Skripsi, Institut Teknologi Nasional, Malang.

Widhiani, dkk. 2013. Pengembangan Metode Kromatografi Gas Detektor lonisasi Nyala Untuk Analisis CO Dan $\mathrm{CO}_{2}$ di Udara. Universitas Udayana. Bali

Wijana, S., dkk. 1991, Optimalisasi Penambahan Tepung Kulit Nanas Dan Proses fermentasi pada pakan Ternak Terhadap Peningkatan Kualitas Nutrisi,

ARMP(Deptan). Universitas Brawijaya, Malang

Winarno, F.G. 1984. Pengantar Teknologi Pangan. PT. Gramedia. Jakarta. 